\title{
The Study of Relationship between Kolb's Learning Styles, Gender and Learning American Slang by Iranian EFL Students
}

\author{
Mariam Biabani \\ Department of English Language Education, Zanjan Branch, Islamic Azad University, \\ Zanjan, Iran,mmbiabani@gmail.com
}

\section{Siros Izadpanah}

Dr., corresponding author, Department of English Language Education, Zanjan Branch, Islamic Azad University, Zanjan, Iran, cyrosizadpanah@yahoo.com

This study aimed to investigate the relationship between Kolb's learning styles and learning slang among Iranian EFL students with a gender-based focus. To this end, 63 EFL students of Tehran University were selected as the participants of the study out of 70 through the proficiency test by simple random sampling. The participants were both genders-27 males and 36 females aged between 18 and 25 in 2017-2018. Using descriptive statistics, correlation, regression and t-test, the data were analyzed. The results of the study indicated a high, significant and positive regression of Kolb's learning style. The highest correlation between Kolb's learning styles and learning American slang was related to the Concrete Experience (CE) and the weakest one was related to the Abstract Conceptualization (AC). The results of the correlation demonstrated positive, significant and high correlation between the Kolb's (2005) learning styles and slang learning. Likewise, the study showed the highest correlation between the experiential learning styles (Concrete Experience, $\mathrm{CE}$ ) and the slang learning. Meanwhile, the study showed non-significant correlation either between gender and slang learning or between gender and learning styles. The implication is that the teacher trainers may include fostering the beneficial learning styles in their lesson plan in order to improve the teachers' teaching.

Keywords: learning styles, slang learning, abstract conceptualization, active experimentation, concrete experience, EFL students

\section{INTRODUCTION}

Learning styles are factors that affect students' learning processes. Learners use different styles based on their individual differences. The recognition of the relationship between learning styles and teaching based on which description will assist lecturers use suitable 
methods of teaching. Teachers should pay attention to their students' individual differences in choosing learning styles (Boström \& Hallin, 2013; Engels \& Gara, 2010; Sudria, Redhana, Kirna, \& Aini, 2018).

Student learning achievement depends on various factors, but the effect of learning models has been questioned (Ulstad, Halvari, Sørebø, \& Deci, 2016; Sudria, et al, 2018). Kolb's model of information styles was developed on the basis of Kolb's experiential learning cycle phases (Kolb, Boyatzis, \& Mainemelis, 2000) involving concrete experience (CE), reflective observation (RO), abstract conceptualization (AC), and active experimentation (AE), which are aligned with the phases of scientific learning. Kolb Learning styles consist of four learning styles: Divergers, Assimilators, Convergers, and Accommodators. Learners learn most successfully through concrete experiences and through reflective observation in the case of the Divergers; through reflective observation and disturb conceptualization for the Assimilators; through abstract conceptualization and active experiments for the Convergers, and through concrete experiences and active experimentation for the Accommodators. Learning languages cause many problems for learners as well as teachers. Communicative competence involves several dimensions, i.e. grammatical, discourse, and pragmatic methods. In fact, language learning at any level and any skill depends on an interaction among these four components or competences.

There are few studies related to American slang and American slangatic expressions, and there is not any study about the relationship between Kolb's Learning Model and Learning American slang among Iranian EFL students.

The main purpose of the study is to determine the relationship between Kolb's Learning Styles and learning American slang among Iranian EFL students. In fact, the following may be considered among the main purposes of the study:

- $\quad$ To determine the relationship between Kolb's Learning Styles and Learning American slang by Iranian EFL Students;

- To determine the effect of gender on the preferred Kolb's Learning Styles and its relation to Learning American slang by Iranian EFL Students (the American slang test scores will be analyzed with respect to their learning styles and gender differences);

- $\quad$ To determine the preferred Kolb's Learning Styles by Iranian EFL Students;

- To determine which Kolb's Learning Styles influence learning American slang by Iranian EFL students.

\section{LITERATURE REVIEW}

Learning strategies should facilitate learners with different learning styles. A learning style refers to the preferred ways to learn such absorbing, processing, and managing information either by remembering, reasoning, and/or problem solving. Kozhevnikov (in Rogowsky, Calhoun, \& Tallal, 2015) concluded that cognitive learning styles represent heuristics and based on which individuals can be grouped with respect to regulatory function they apply to multiple levels of information processing from perceptual to 
metacognitive. Learning style is a combination of how learners absorb and then organize information.

Kolb's model was designed based on empirical learning. According to Kolb and Kolb (2005), learning involves a series of human activities, including sensation, reflex, thinking and doing. Based on Kolb's model, the four main learning abilities are reflection observation, concrete experiences, active experiment and abstract conceptualization. A person's preference for using any one of these four items will develop a different learning style. Thus, the four learning styles are divergent, convergent, assimilative and accommodative. Each of the learning styles has weak points and positive points; the perfect learner is someone who uses different styles in different situations appropriately (Kolb \& Kolb, 2005; Reshmad'sa, \& Vijayakumari,. (2017).).

Kolb (1984) provides "a comprehensive theory which offers the foundation for an style to education and learning as a lifelong process and which is soundly based in intellectual traditions of philosophy and cognitive and social psychology" (Akpan \& Beard, 2016; Zuber- Skerritt 1992a, 98; Yousafzai, Baseer, Fatima, , Ali, \& Shah,. (2018). Vizeshfar, \& Torabizadeh, (2018). Kolb's model can be used as a description of the learning process in general (Henry, 1989), but his emphasis on reflection places it firmly in the experience-based learning camp. The importance of reflection is emphasized by Boreham $(1987,89)$, who notes that "the term 'learning from experience' really means learning from reflection on experience". A similar point is made by Boud (1985), who coined a slogan in the title of their book Reflection: turning experience into learning.

There are still many theoreticians who see slang as decadent, undesirable, and uneducated. Some researcher personally and firmly believes that slang is no longer a taboo as it once was and this assumption is totally absurd (Kolb \& Fry, 1975; Smith,., \& Rayfield, (2017).). Slang is a sign of life, vibrancy, and beauty in language. It is a living thing and no one can stop it from changing (In'am, Akhsanul, \& Hajar, 2017; Stoneback, 2014).

Utilizing American slang is an essential skill needed to function in today's society. Not only does slang occur in everyday social interactions, it is also used in classrooms by peers and professors. In spite of this, many ESL students are not taught slang in preparation for university life. As a result, these students struggle to understand conversations and participate in discussions that include colloquial language. By teaching slang in the classroom, we can prepare our students for real world interactions.

\section{Learning styles: Theoretical Definitions}

Learning styles suggest styles and directions in learning which differentiate learners in their preferences for learning. In this regard, Gunes (2004) considers learning style as the style which is followed by an individual in tackling the learning task in processing, retaining and analyzing the incoming information or language input. Learning styles demand a vast variety of channels based on the characteristics of the learners as visual, auditory, kinesthetic (Slavin, 2000). Hence, learning styles refer to the relatively 
permanent direction in utilization and response to the particular language input that the language learners are exposed to the educational contexts.

Most studies done in the area of lexis argue that vocabulary should be placed at the center of language teaching because language consists of grammaticalized lexis, not lexicalized grammar. Lewis (1993) argued that, the lexical style is a shift in language teaching from grammar to vocabulary teaching, as 'language consists not of traditional grammar and vocabulary, but often of multi-word prefabricated chunks' (Lewis, 1997). These chunks may include slang collocations, fixed and semi-fixed expressions. These chunks are also called 'formulaic language'. Schmitt (2000) argued that 'Formulaic language occupies a crucial role in facilitating language; it is the key to fluency and motivates the learner'.

\section{American slang: Theoretical Definitions}

American slang is not considered part of the standard vocabulary of a language and that is used very informally in speech ... (Rundell \& Fox, 2007). Meanwhile, American slang learning demands a pre-requisite 3000 vocabulary size (McGavigan, 2009) which indicates the complicated nature of American slang learning. Abel (2003), in a similar vein, stresses on the difference between the literal meaning of the individual words and figurative meaning which is implied from the American slang and informal expressions. Similarly, McCarthy and O'Dell (2003) consider American slang as a fixed expression whose meaning is totally different from the meaning of individual words which compose it.

Hence, an American slang is a multi-word expression which has a fixed order with a non-literary meaning and that has to be learned in association with cultural, pragmatic and sociological use (Saberian, \& Fotovatnia, 2011).

Hence, American slang learning, according to Rodriguez and Winnberg (2013), demands cultural knowledge. Nippold and Taylor (2002), in a similar vein, consider the cultural knowledge as the pre-requisite for American slang learning which starts in childhood and improves over the lifetime of any speaker. Nippold, Maron and Schwarts (2001) are among the researchers who consider culture, context, academic literacy and world knowledge as the variables which influence the process of American slang learning.

\section{Empirical Studies on Learning styles in relation to Language Learning}

In this section, some empirical studies are mentioned in order to shed light on the direction of the relation between language learning including American slang learning and learning styles. Nasab and Hesabi (2014) explored the association between the learning styles and the use of pictures in comprehension of American slangsatic expressions among Iranian EFL learners. To this end, 39 Iranian B.A University students who were studying English literature major were selected in two intact classes as the participants of the study and went through different instructions on number some American slangs. One of the group just received definitions and examples for American slangs and the other pictures in addition to the definitions and examples. The results of 
the study indicated a significant correlation "between the participants' learning styles and their comprehension of American slangs in the picture group" (Nasab \& Hesabi, 2014, p. 1892).

Moser, and Zumbach, (2018) conducted a research on exploring the development and impact of learning styles: An empirical investigation based on explicit and implicit measures. It is still controversial whether learning styles are unchangeable dispositions or flexible characteristics. Research on the development of learning styles is therefore in high demand. They suggest a conceptual model that describes both explicit and implicit cognitive processes involved in processing instructional material. They also propose an implicit association test (learning styles IAT). In a first study $(\mathrm{N}=126)$, they evaluate the stimulus material for the IAT. In a second study $(\mathrm{N}=104)$, they investigate the correlations between the implicit and explicit measures used. They further examine interactions between learning styles and learning outcomes as well as cognitive load. Two versions of a computer-based learning program (verbal vs. visual presentation of information) were used. The results reveal that matching learning styles and learning materials neither leads to better learning outcomes nor to a lower cognitive load. Additionally, neither implicit nor explicit measures were able to predict learning outcomes

Zhu, Zeng, Zhang, Wan, Guo, and Zhang (2018) conducted a research on the preferred learning styles utilizing VARK among nursing students with bachelor degrees and associate degrees in China. This study aimed to determine the differences in learning style preferences among bachelor degree nursing students at Central South University and associate degree nursing students at the Vocational Health School in China. This study was a cross-sectional survey using the Chinese version of the VARK questionnaire to assess preferred learning styles: 159 enrolled bachelor degree nursing students and 199 enrolled associate degree nursing students completed the questionnaire with a response rate of $96.8 \%$. The bachelor degree nursing students tend to prefer a multimodal learning style $(58.49 \%)$, which significantly differed from that of associate degree nursing students $(45.77 \%)$. The kinaesthetic modality was the predominant unimodal learning style among the bachelor degree and associate degree nursing students $(18.20 \%$ and $33.67 \%)$, and the read-write modality was the least popular modality $(2.5 \%$ and $4.02 \%)$.

Cuevas, and Dawson, (2018) conducted a research on testing of two alternative cognitive processing models: Learning styles and dual coding. This study tested two cognitive models, learning styles and dual coding, which make contradictory predictions about how learners process and retain visual and auditory information. Learning stylesbased instructional practices are common in educational environments despite a questionable research base, while the use of dual coding is less ubiquitous, and thus measured examination of the two methods has implications for practical application. The study involved 204 university students who were surveyed on their preferred learning style and then presented with information that they were prompted to process via either imagery or linguistic means. The results showed there was no significant interaction effect between learning style and condition, suggesting the most basic 
prediction of the learning styles hypothesis should be rejected. In a regression analysis, none of the four learning styles (visual, auditory, read/write, or kinesthetic) predicted students' retention of the material. However, there was a highly significant main effect of condition with those in the visual condition retaining twice as much information as those in the auditory condition regardless of learning style, a result that strongly supports dual coding theory.

Alzain, Clark, Ireson, and Jwaid, (2018) conducted a research on adaptive education based on learning styles: are learning style instruments precise enough? Investigating the efficiency of learning style instruments is significant because it is a widespread technique and it enriches the understanding of the challenges of integrating such instruments into adaptive education systems. The results showed that current learning style instruments depend only on the textual form of information to present items; this might be leading to a bias in the measurement of learning styles as the textual forms of information are more suitable for verbal students than for others. The purpose of this paper is to investigate the precision of learning style instruments and the challenges of integrating them into adaptive education systems. This research followed a quantitative research approach. First, a new learning style instrument was developed using different forms of information (Figures, Charts, and Equations). Then, the preferred learning style of fifty students was measured twice, initially, by using the newly developed instrument and subsequently by using a VARK instrument, the results of both were compared.

Barzegar and Tajalli (2013) conducted a study in order to examine whether there was any relationship between Iranian's EFL language learning styles and their classroom achievements. To this end, 60 female EFL learners were selected as the participants of the study who were asked to answer Reid's (1987) language learning styles questionnaire. The data was put into the SPSS and were analyzed in terms of its correlation with the learners' classroom achievements which resulted into the positive correlation in which the kinesthetic and group learning styles were the dominant ones.

Günes (2004) explored the association between the learning styles preferences and gender, proficiency level of English and achievement scores on listening, reading, grammar, and writing in the English Course of the students. To this end, 367 students were selected as the subjects of the study which resulted into non-significant difference between students' learning styles preferences, gender, as well as level and achievement scores.

Khalid (2013) investigated the relationship between the students' learning styles and their academic achievements. To this end, 100 students were selected as the participants of the study who were asked to answer to the six dimensions of Grasha-Riechmann Learning styles Scale which correspond with free-style, avoidance, cooperation, dependent, competition, and participation. The researchers found that there is nonsignificant correlation between learning styles and academic achievements.

Kadir (2013) examined the relationship between the Malaysian students' learning styles and academic performance. To this end, the researcher utilized the Dunn and Dunn learning styles model. He found that there is significant relationship among the five environmental dimensions, namely, environment, emotional, sociological, physiological 
and psychological. Meanwhile, the researcher concluded that the emotional dimension was the strongest dimension in relation to the educational performance.

Mohammadzadeh (2012), on the other hand, investigated the associations between the experiential learning styles and the immediate and delayed retention of English collocations among EFL Learners. To this end, 75 EFL students were selected as the participants of the study who took a learning style inventory along with the pre-test on collocation knowledge. After that the subjects went under instruction in terms of some English collocations. The researcher found that there are significant differences among the students due to their dominant learning styles in terms of delayed and immediate learning with the outperformance of the group with the dominant diverged learning style.

Worley-Davis (2012) explored university students' learning styles and their association with their academic performance. It was found that there are non-significant differences among the students in terms of their dominant learning styles. In fact, the concrete perceptual quality and sequential ordering capability were the dominant learning styles among them. Meanwhile, non-significant relationship was found between the two variables of the learning styles and academic performance.

\section{METHOD}

\section{Setting and Participants}

The participants of the study were 63 EFL BA students studying English in the Tehran University who were selected out of 70 from two classes (they were selected through simple random sampling). The participants were from both genders- 27 males and 36 females with the age between 18 and 25. The included participants were mainly Persian native language with English as their foreign language. In selecting participants, random sampling procedure was utilized. In fact, two classes were selected randomly and the participants took the Solutions Placement Test: Elementary to Intermediate which was developed by Edwards (2007), out of them, the participants whose scores were one standard deviation (4.24) above and below the mean score (27.47) were included. Meanwhile, $43 \%$ of the participants were males and $57 \%$ females.

\section{Design of the Study}

Following a correlational design, the relationship between learning American slang expressions and learning styles among Iranian EFL students was investigated. Likewise, the relationship between gender with each variable of learning styles and learning American slang expressions were also investigated. It was worth mentioning that this study was a correlational one in which we could just discuss existence of an association among variables.

\section{Instrumentations}

\section{Data Collection Procedures}

The instruments for collecting data were two tests and one questionnaire: Elementary to Intermediate which was developed by Edwards (2007), Kolb's (2006) Learning Style Inventory questionnaire, and an American Slang Test (version 2006). 
The Solutions Placement Test: Elementary to Intermediate which was developed by Edwards (2007) composed of two parts of grammar and vocabulary (50 items), and reading (one passage and 5 items). Kolb's (2006) Learning Style Inventory questionnaire composed of 80 items among which the students needed to choose the ones appropriate for them. The items of the Kolb's (2006) Learning Style Inventory questionnaire were related to different learning styles of activist, reflector, theorist and pragmatist. The American Slang Test (version 2006) composed of 15 multiple-choice items. Table 1 shows the characteristics of each test or questionnaire.

Table 1

Characteristics of the Instrumentations

\begin{tabular}{|c|c|c|c|}
\hline Test/Questionnaire & Number of Items & Characteristics & Scoring Procedures \\
\hline $\begin{array}{l}\text { Solutions } \\
\text { Placement Test: } \\
\text { Elementary to } \\
\text { Intermediate } \\
\end{array}$ & 55 & $\begin{array}{l}\text { Multiple- } \\
\text { choice items }\end{array}$ & $\begin{array}{l}\text { Based on the key answer for } \\
\text { each item there is only one } \\
\text { correct choice; }\end{array}$ \\
\hline $\begin{array}{l}\text { Kolb’s (2006) } \\
\text { Learning Style } \\
\text { Inventory } \\
\text { questionnaire }\end{array}$ & 80 & $\begin{array}{l}\text { Simple } \\
\text { statements out } \\
\text { of the which } \\
\text { the subjects } \\
\text { select }\end{array}$ & $\begin{array}{l}\text { Select the desired statements; } \\
\text { no-correct answer; four sets of } \\
\text { questions for a four-way } \\
\text { classification; }\end{array}$ \\
\hline $\begin{array}{l}\text { The American } \\
\text { Slang Test (version } \\
\text { 2006) }\end{array}$ & 15 & $\begin{array}{l}\text { Multiple- } \\
\text { choice items }\end{array}$ & $\begin{array}{l}\text { Based on the key answer for } \\
\text { each item there is only one } \\
\text { correct choice; }\end{array}$ \\
\hline
\end{tabular}

The randomized participants (63 out of 70) were divided into two groups-32 and 31(both groups almost with the same features in sex, age and level of education) and this group did not receive any instruction about teaching, learning and using of American slangs.

Since the Solutions Placement Test: Elementary to Intermediate (SPT) and The American Slang Test (IT) (version 2006) the standard and international tests, they had the appropriate validity - all of them covered the domain which was interested in the study, had face validity, content validity and construct validity. In terms of reliability, Solutions Placement Test: Elementary to Intermediate (SPT) and The American Slang Test (IT) (version 2006) were administered to the EFL students of Tehran University and the results according to the tables showed the acceptable reliability level.

\section{Data Analysis Procedures}

In this section Spearman's rank order correlation (Rho) statistic were used to consider the relationship between two variables (between learning styles and American slang learning to consider the relation among the variables, i.e. learning styles and American slang learning. Spearman's rank order correlation (Rho) shows a statistic which calculated the relationship between two variables - at least one of them is nonparametric (learning style is non-parametric). Multiple regression, was used to measure the association among several variables (at least three). So, multiple regression was used 
in order to calculate the association among Kolb's learning styles, gender and American slang test score.

\section{Main Study}

Initially, the homogeneity of the participants' informal communication proficiency based on using American slang was checked. To this end, the questionnaires were distributed to the participants-Solutions Placement Test: Elementary to Intermediate which was developed by Edwards (2007).

Then, the scores were submitted to SPSS22. First of all, the inter-rater reliability was checked via Cronbach's alpha, and a relatively high reliability was achieved $(\alpha=.89)$. After that, the normality of the data was examined via the one-sample KolmogorovSmirnov (K-S) test and Shapiro-Wilk test.

\section{FINDINGS}

\section{Kolb's Learning Styles among the Participants: Descriptive Statistics}

The first variable investigated in the study was the Kolb's Learning Styles among the participants. Table 2 illustrates the descriptive statistics of the dominant learning styles among the participants using the Kolb's learning model. It is worth mentioning that sum of each style was also computed as the table shows.

Table 2

Kolb's Learning Styles among the Participants: Descriptive Statistics

\begin{tabular}{llllll}
\hline & $\mathrm{N}$ & Minimum & Maximum & Mean & Std. Deviation \\
\hline $\mathrm{CE}$ & 63 & 6.00 & 16.00 & 10.95 & 2.58 \\
\hline $\mathrm{RO}$ & 63 & 3.00 & 15.00 & 8.98 & 2.76 \\
\hline $\mathrm{AE}$ & 63 & 10.00 & 18.00 & 13.60 & 2.09 \\
\hline $\mathrm{AC}$ & 63 & 12.00 & 19.00 & 16.00 & 1.89 \\
\hline Styles & 63 & 34.00 & 66.00 & 49.53 & 8.58 \\
\hline
\end{tabular}

The participants of the study were 63 EFL students whose dominant styles and sum of the studies were presented in the table. The four styles demonstrated by the Kolb's Learning Styles are Concrete Experience (CE), Reflective Observation (RO), Active Experimentation (AE), and Abstract Conceptualization (AC).

The Concrete Experience (CE) learning style showed the minimum of 6 and maximum of 16 with the mean about 11 and standard deviation of 2.5 among Iranian EFL students. Likewise, the Reflective Observation (RO) revealed the minimum of 3 and maximum of 15 with the mean about 9 and standard deviation of about 2 among Iranian EFL students. Moreover, the Active Experimentation (AE) illustrated the minimum of 10 and maximum of 18 with the mean about 13.5 and standard deviation of about 2 among Iranian EFL students. Finally, the Abstract Conceptualization (AC) demonstrated the minimum of 12 and maximum of 19 with the mean 16 and standard deviation of about 2 among Iranian EFL students. 
Table 3

Kolb's Learning Styles among the Participants: Females vs. Males

\begin{tabular}{llllll}
\hline & gender & $\mathrm{N}$ & Mean & Std. Deviation & Std. Error Mean \\
\hline $\mathrm{CE}$ & =female & 37 & 10.75 & 2.47 & .40 \\
\cline { 2 - 6 } & $=$ male & 26 & 11.23 & 2.76 & .54 \\
\hline \multirow{2}{*}{$\mathrm{NO}$} & $=$ female & 37 & 8.78 & 2.96 & .48 \\
\cline { 2 - 6 } & $=$ male & 26 & 9.26 & 2.49 & .48 \\
\hline \multirow{2}{*}{ AE } & $=$ female & 37 & 13.62 & 2.11 & .34 \\
& =male & 26 & 13.57 & 2.10 & .41 \\
\hline \multirow{2}{*}{ AC } & $=$ female & 37 & 15.97 & 1.92 & .31 \\
& =male & 26 & 16.03 & 1.88 & .36 \\
\hline \multirow{2}{*}{ Style1 } & $=$ female & 37 & 49.13 & 8.75 & 1.44 \\
& $=$ =male & 26 & 50.11 & 8.45 & 1.65 \\
\hline
\end{tabular}

The Reflective Observation (RO), on the other hand, revealed the mean of 8.78 and the standard deviation of about 3 among the female participants. Meanwhile, the male participants showed the mean of 9.26 and the SD of 2.50. The Active Experimentation (AE) demonstrated the mean of 13.62 and the standard deviation of 2.13 among the female participants. Meanwhile, the male participants showed the mean of 13.57 and the SD of 2.10. Finally, the Abstract Conceptualization (AC) illustrated the mean of about 16 for the both genders and the standard deviation of about 2 for the both genders. Meanwhile, the male participants showed higher utilization the styles where males' share showed the mean about 49 for female and 50 for males. Likewise, the SD for the females was 8.75 and for male about 8.50. Considering figure 1 which sheds light on the mean utilization of each style for the both genders clarifies that the both genders have relatively similar tendency in their utilization of the styles.

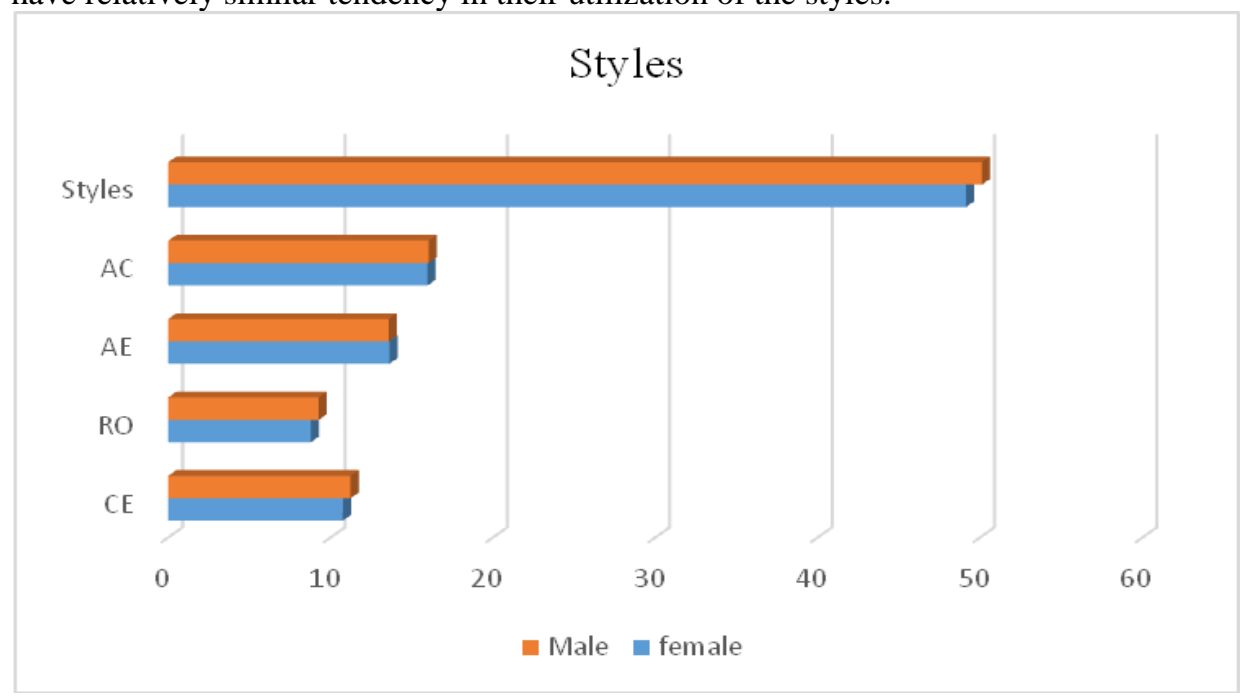

Figure 1

Kolb's Learning Styles among the Participants: Females vs. Males 


\section{American slang and informal words in communication among the Participants: Descriptive Statistics}

The second variable explored in the study was the participants' proficiency in comprehending the American slang and informal words in communication.

Table 4

American slang and informal words in communication among the Participants:

Descriptive Statistics

\begin{tabular}{llllll}
\hline & $\mathrm{N}$ & Minimum & Maximum & Mean & Std. Deviation \\
\hline slang & 63 & 5.00 & 15.00 & 9.79 & 3.24 \\
\hline
\end{tabular}

The table shows that the minimum score on the slang quiz was 5 and the maximum of 15 with the mean about 10 and the standard deviation about 3. Table 4 compares the performances of the participants on the slang exam.

Table 5

American slang and informal words in communication among the Participants:

Females vs. Males

\begin{tabular}{llllll}
\hline & gender & $\mathrm{N}$ & Mean & Std. Deviation & Std. Error Mean \\
\hline \multirow{3}{*}{ slang } & $=$ female & 37 & 9.62 & 3.17 & .52 \\
\cline { 2 - 6 } & $=$ male & 26 & 10.03 & 3.38 & .66 \\
\hline
\end{tabular}

As the table demonstrates the female participants have the mean of 9.62 and the standard deviation of 3.17. Moreover, the male participants showed the mean of about 10 and standard deviation about 3 . Figure 2 demonstrates the issue clearly.

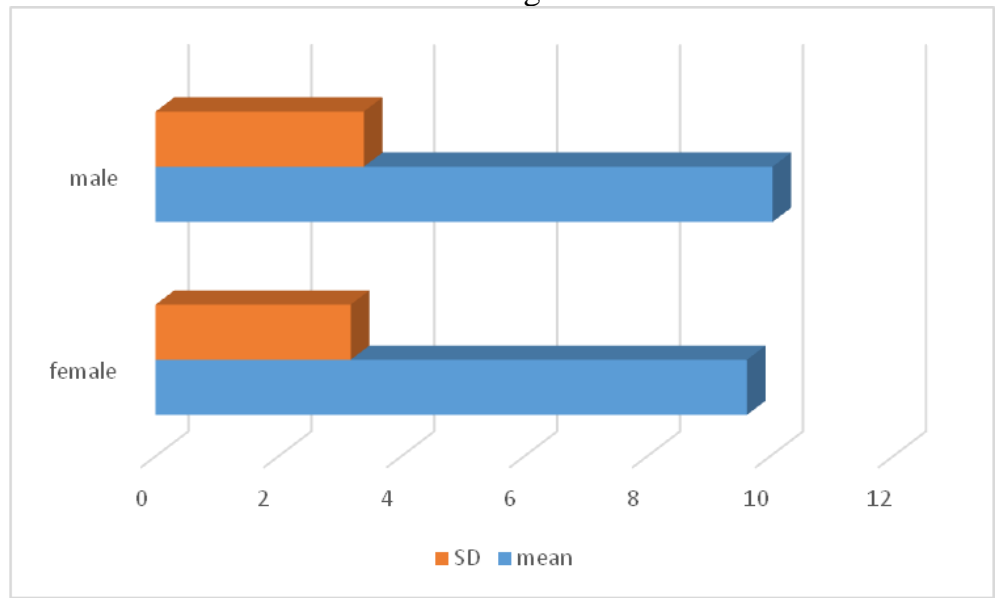

Figure 2

Slangaticity among the Participants: Females vs. Males

\section{Association between the Variables}

In this section, the correlation between the variables, i.e. between different types of styles as well as between each learning style and slang performance of the participants 
were investigated. In addition, the variable of gender was examined in relation to learning style as well as in relation to its components and in relation to American slang and informal words in communication.

\section{The Total Learning style and Each Type of Kolb's learning styles}

Table 6 demonstrates the relationship between each type of learning styles with the others as well as with learning styles in general. The results of the two-tailed test at the level of 0.01 illustrates a significant positive correlation between each type of Kolb Leaning Style (KLS) and the total learning style.

Table 6

Associations between the Kolb's Learning Styles

\begin{tabular}{|c|c|c|c|c|c|c|}
\hline & & Style & $\mathrm{CE}$ & RO & $\mathrm{AE}$ & $\mathrm{AC}$ \\
\hline \multirow[t]{3}{*}{ Style } & Correlation Coefficient & 1.000 & $.952^{* * *}$ & $.910^{* * *}$ & $.912^{* *}$ & $.861^{* * 1}$ \\
\hline & Sig. (2-tailed) & & .000 & .000 & .000 & .000 \\
\hline & $\mathrm{N}$ & 63 & 63 & 63 & 63 & 63 \\
\hline \multirow[t]{3}{*}{$\overline{\mathrm{CE}}$} & Correlation Coefficient & $.952^{* * *}$ & 1.000 & $.917^{* *}$ & $.822^{* * *}$ & $.719^{* * 4}$ \\
\hline & $\overline{\text { Sig. (2-tailed) }}$ & .000 & & .000 & .000 & .000 \\
\hline & $\mathrm{N}$ & 63 & 63 & 63 & 63 & 63 \\
\hline \multirow[t]{3}{*}{$\overline{\mathrm{RO}}$} & Correlation Coefficient & $.910^{* * *}$ & $.917^{* * *}$ & 1.000 & $.735^{* *}$ & $.631^{* * *}$ \\
\hline & Sig. (2-tailed) & .000 & .000 & . & .000 & .000 \\
\hline & $\mathrm{N}$ & 63 & 63 & 63 & 63 & 63 \\
\hline \multirow[t]{3}{*}{$\overline{\mathrm{AE}}$} & Correlation Coefficient & $.912^{* *}$ & $.822^{* * *}$ & $.735^{* *}$ & 1.000 & $.896^{* *}$ \\
\hline & Sig. (2-tailed) & .000 & .000 & .000 & & .000 \\
\hline & $\mathrm{N}$ & 63 & 63 & 63 & 63 & 63 \\
\hline \multirow[t]{3}{*}{$\overline{\mathrm{AC}}$} & Correlation Coefficient & $.861^{*}$ & $.719^{* * * *}$ & $.631^{*}$ & $.896^{* * *}$ & 1.000 \\
\hline & Sig. (2-tailed) & .000 & .000 & .000 & .000 & \\
\hline & $\overline{\mathrm{N}}$ & 63 & 63 & 63 & 63 & 63 \\
\hline
\end{tabular}

Likewise, the correlation between the total learning style and the Concrete Experience (CE) is 0.952 which demonstrates a high and significant correlation where the p-value is 0.000. Moreover, the correlation between the total learning style and the Reflective Observation (RO) is 0.910 which is also a high and significant correlation with the pvalue of 0.000 .

Furthermore, the correlation between the total learning style and the Active Experimentation (AE) is 0.912 which shows a high and significant correlation with the p-value of 0.000 . Finally, the correlation between the total learning style and the Abstract Conceptualization (AC) is 0.861 which is significant at the level of 0.01 with the p-value of 0.000 .

Generally, all the four types of Kolb Learning styles revealed to correlate significantly and strongly with the general learning styles; however, the greatest correlation was found to be by the Concrete Experience (CE).

Meanwhile different four learning styles are highly associated significantly and positively. Likewise, the correlation between the Concrete Experience (CE) and the Reflective Observation (RO) is 0.917 . 
Moreover, the correlation between the Concrete Experience (CE) and the Active Experimentation (AE) is 0.822. Furthermore, the correlation between the Concrete Experience (CE) and the Abstract Conceptualization (AC) is 0.719. In addition, the correlation between the Reflective Observation (RO) and the Active Experimentation (AE) is 0.735 .

Moreover, the correlation between the Abstract Conceptualization (AC) as well as the Reflective Observation (RO) and Active Experimentation (AE) are 0.631 and 0. 896, respectively. It is worth mentioning that the p-value for all of them is 0.000 which indicates a significant correlation.

\section{Learning styles and Gender}

Examining the relationship between the total learning style as well as its types and gender is represented in table 7

Table 7

Associations between Gender \& the Kolb's Learning styles

\begin{tabular}{llllllll}
\hline \multirow{3}{*}{ gender } & & Style & CE & RO & AE & AC & gender \\
\cline { 2 - 8 } & Correlation Coefficient & .053 & .093 & .090 & .003 & .031 & 1.000 \\
\cline { 2 - 8 } & Sig. (2-tailed) & .679 & .470 & .483 & .983 & .807 &. \\
\cline { 2 - 8 } & $\mathrm{N}$ & 63 & 63 & 63 & 63 & 63 & 63 \\
\hline
\end{tabular}

Considering the results of table 7 shows that gender plays a neutral role where gender is not significantly correlated with the total learning style as well as with each type of Kolb's Learning Styles. In fact, the correlation between a gender and each type of learning styles and total learning style is very weak below 0.01 and the p-value is much higher than the cut-score of 0.01 or even 0.05 .

\section{Learning styles and Slang}

The total learning style and its types also were examined in relation to the slang learning among the participants. Table 8 demonstrates the results of the correlation.

Table 8

Associations between Slang Learning \& the Kolb's Learning styles

\begin{tabular}{llllllll}
\hline \multirow{2}{*}{ Spearman's rho slang } & & Slang & Style & CE & RO & AE & AC \\
\cline { 2 - 8 } & Coefrelation & 1.000 & $.854^{* *}$ & $.868^{* *}$ & $.804^{* *}$ & $.732^{* *}$ & $.645^{* *}$ \\
\cline { 2 - 8 } & Sig. (2-tailed) &. & .000 & .000 & .000 & .000 & .000 \\
\cline { 2 - 8 } & $\mathrm{N}$ & 63 & 63 & 63 & 63 & 63 & 63 \\
\hline
\end{tabular}

As the table shows slang learning is significantly and positively correlated not only with the total learning style but also with the four types of the Kolb's Learning Styles due to the results of the two-tailed test which is 0.000 for all of them. The correlation between slang learning and total style is 0.854 . Likewise, the correlation value between the slang learning and the four types of learning styles, i.e. Concrete Experience (CE), Reflective Observation (RO), Active Experimentation (AE), and Abstract Conceptualization (AC) are respective, $0.868,0.804,0.732$, and 0.645 . Hence, the highest correlation is related to the Concrete Experience $(\mathrm{CE})$. The table illustrates the correlation between slang and 
learning styles. Considering the fissure shows that highest correlation is related to the Concrete Experience (CE) and the weakest one is related to the Abstract Conceptualization (AC).

\section{Slang and Gender}

Exploring correlation between gender and slang revealed to be non-significant. As table 9 demonstrates the p-value is 0.637 and the correlation is 0.61 which is very weak. It indicates that gender is not a variable in slang learning.

Table 9

Associations between Slang \& Gender

\begin{tabular}{|c|c|c|}
\hline & & gender \\
\hline \multirow[t]{3}{*}{ Spearman's rho } & Correlation Coefficient & .061 \\
\hline & Sig. (2-tailed) & .637 \\
\hline & $\overline{\mathrm{N}}$ & 63 \\
\hline
\end{tabular}

\section{Association among the Variables}

Considering slang learning as dependent variable and learning styles and gender as the constant and independent variables, multiple regression was also explored.

Table 10

Correlational Statistics: Multiple Regression

\begin{tabular}{|c|c|c|c|c|c|c|}
\hline \multicolumn{2}{|c|}{ Model } & Sum of Squares & $\mathrm{df}$ & Mean Square & $\mathrm{F}$ & Sig. \\
\hline \multirow[t]{3}{*}{1} & Regression & 481.265 & 5 & 96.253 & 32.074 & $.000^{\mathrm{b}}$ \\
\hline & Residual & 171.053 & 57 & 3.001 & & \\
\hline & Total & 652.317 & 62 & & & \\
\hline
\end{tabular}

b. Predictors: (Constant), CE, gender, AC, $\mathrm{RO}, \mathrm{AE}$

Table 10 indicates a significant regression among the variables, namely, total learning style, the four types of Kolb's learning styles and gender with the slang. The average $(\mathrm{b}=0.884)$ is significant $(\mathrm{p}=0.01)$, and the coefficient is positive for slang learning only in relation to the Concrete Experience which indicates that the greater level of the Concrete Experience (CE), the higher level of slang learning or performance. Next, the effect of gender, Active Experimentation (AE) Learning style, Reflective Observation (RO) learning style and abstract Conceptualization (AC) learning style as well as the total learning style are non-significant ( $p$-value is much higher than the cut score) and their coefficient is negative indicating that females and the subjects outperformed in terms of writing. 
Table 11

Coefficient Statistics: Multiple Regression

\begin{tabular}{|c|c|c|c|c|c|c|}
\hline \multirow[b]{2}{*}{ Model } & & \multicolumn{2}{|c|}{ Unstandardized Coefficients } & \multirow{2}{*}{$\begin{array}{l}\text { Standardized } \\
\text { Coefficients } \\
\text { Beta } \\
\end{array}$} & \multirow[b]{2}{*}{$\mathrm{T}$} & \multirow[b]{2}{*}{ Sig. } \\
\hline & & B & Std. Error & & & \\
\hline \multirow[t]{6}{*}{1} & (Constant) & -3.214 & 2.075 & & -1.549 & .127 \\
\hline & gender & -.049 & .454 & -.007 & -.107 & .915 \\
\hline & $\mathrm{AC}$ & .095 & .249 & .055 & .379 & .706 \\
\hline & $\overline{\mathrm{AE}}$ & .079 & .308 & .051 & .256 & .799 \\
\hline & $\overline{\mathrm{RO}}$ & .091 & .180 & .077 & .504 & .616 \\
\hline & $\overline{\mathrm{CE}}$ & .884 & .245 & .705 & 3.604 & .001 \\
\hline
\end{tabular}

\section{Comparison between the Two Genders}

In a further step, the researcher endeavored to examine the differences between the two genders in terms of the slang learning and learning styles along with its type in order to determine if there is any significant difference between them.

Table 12

Normality Distribution Test

\begin{tabular}{lllllll}
\hline & \multicolumn{2}{l}{ Kolmogorov-Smirnov $^{\mathrm{a}}$} & \multicolumn{3}{l}{ Shapiro-Wilk } \\
\cline { 2 - 7 } & Statistic & $\mathrm{df}$ & Sig. & Statistic & $\mathrm{df}$ & Sig. \\
\hline slang & .154 & 63 & .071 & .920 & 63 & .081 \\
\hline $\mathrm{CE}$ & .183 & 63 & .007 & .950 & 63 & .08 \\
\hline $\mathrm{RO}$ & .112 & 63 & .046 & .975 & 63 & .240 \\
$\mathrm{AE}$ & .223 & 63 & .09 & .908 & 63 & .09 \\
\hline $\mathrm{AC}$ & .130 & 63 & .070 & .952 & 63 & .15 \\
\hline Style1 & .136 & 63 & .15 & .955 & 63 & .12 \\
\hline
\end{tabular}

In realizing the aim, normality exploration test was run which indicated to the normality distribution due to the p-value which is lower than the cut score of 0.05 . Accordingly, the t-test statistic was applied since its pre-requisite condition is realized. Table 13 demonstrates the results of the Chi-square test. 
Table 13

Chi-square Test: Females vs. Males

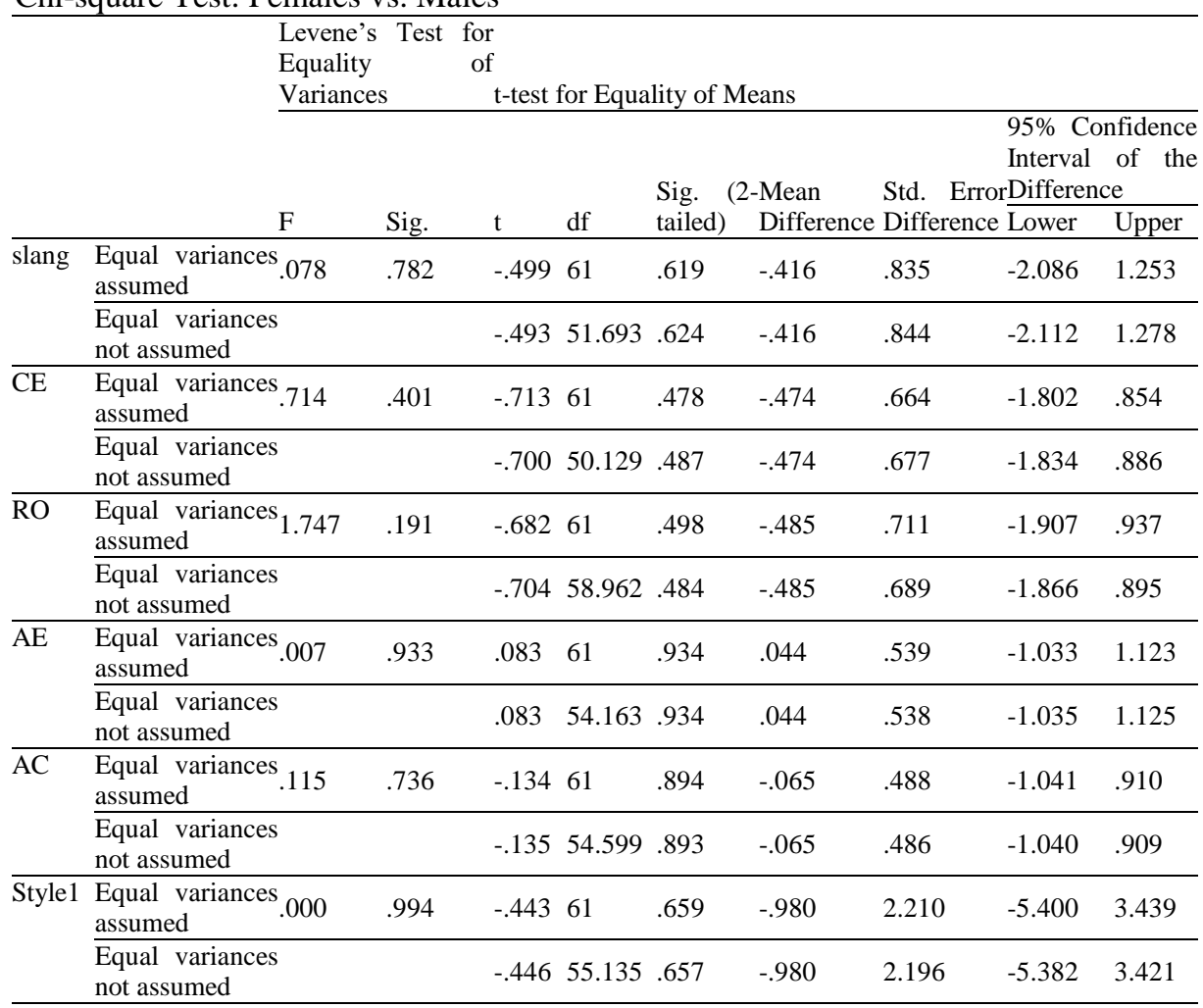

Table 13 shows that the p-value (2-tailed) is much higher than the cut score of 0.01 which indicates to the non-significant performance between the two genders in dealing with the four types of Kolb's Learning Styles, the total learning style and the slang learning. The next section was devoted to the discussion where the raised questions are answered and some bases are presented in supporting or rejecting the suggested hypotheses.

\section{DISCUSSION}

Kolb's (2005) learning styles refer to a model composed of four types of learning styles which differentiate individuals in terms of managing, grouping, perceiving and organizing information organizing. To this end, four different types of learning styles are presented as Concrete Experience (CE), Reflective Observation (RO), Abstract Conceptualization (AC), and Active Experimentation (AE).

In exploring the relationship between the slang learning and Kolb's learning styles, four questions were raised which the researcher tried to find some bases in answering them. 
The first question tried to clarify the relationship between the two variables of the slang learning and Kolb's learning styles among Iranian EFL students. The results of the study indicated not only a significant and correlation between the total learning style and slang learning, but also a significant and positive correlation between the slang learning and all four types of Kolb's learning styles. It is worth mentioning that a combination of the Concrete Experience (CE) and the Abstract Conceptualization (AC) revealed to be the greatest correlation with the slang learning.

Accordingly, the first hypothesis which suggested a null hypothesis where no-relation was indicated about the relationship between the two variables was rejected. In fact, the findings of the study are supporting Nasab and Hesabi (2014) who also argue about a significant correlation between the two variables. The results were consistent with the learning styles identified by Swari (2015) that the same secondary school and SMAN4 Singaraja which had relatively better academic input in Singaraja were dominantly of Convergers, but with no concern with learning model applied. Likewise, the results of the study, instead of a particular learning style which some studies consider the Concert Experience (CE) (Mohammadzadeh, 2012), showed the balance among the four learning styles is also fundamental; however, the most contribution was attributed to the CE.

The second raised question, the study endeavors to answer, was whether there is any relationship between gender and Kolb's Learning Model among Iranian EFL Students. Analyzing the data demonstrates that there is non-significant correlation between gender and the total learning style as well as each four types of Kolb's Learning Styles. Put it in another way, both female's and male's participants performed similarly in terms of Kolb's Learning Styles. Hence, the second suggested hypothesis which considered nonsignificant relationship between gender and Kolb's Learning Model among Iranian EFL students was supported.

Considering the non-significant relationship between gender and learning styles is in line with Günes' (2004) finding whose study also showed that gender is not an indicating variable for learning styles.

Finally, considering gender and learning styles as the fixed and indicator variables, the study attempted to examine the relationship between these two variables and their interaction with the slang learning among the Iranian EFL students. The results of the study illustrated that there is a significant regression among the variables, namely, total learning style, the four types of Kolb's learning styles and gender with the slang learning. Meanwhile, Concrete Experience (CE) learning style was found to play the greatest role in the slang learning among the participants.

Accordingly, the third hypothesis which argued that there is relationship among gender, Kolb's Learning Model, and Learning Slangs by Iranian EFL students was also rejected due to the contradicting findings of the study.

Generally, the study showed that gender is not a variable differentiating between females and males in terms of their dominant learning styles and accordingly in their performance in slang learning. However, the study showed significant relationship between Kolb's Learning styles and slang learning; non-significant relationship was 
found between gender and slang learning as well as between gender and Kolb's learning styles. In other words, gender is an indicator neither for learning styles nor for slang learning. Likewise, learning styles and its types are indicator for slang learning among the participants.

Finally, the fourth hypothesis, the results of the study showed that the Abstract Conceptualization (AC), followed by the Active Experimentation (AE) are the most dominant learning styles among the participants. The results of the study indicated a high, significant and positive regression total learning styles.

Lane (2001) is one of the researchers who argues that learning styles lead into improvement in the attitudes of the participants which in its turn may results into improvement of academic achievements, creativity or productivity. The results of the study which showed significant relationships between slang learning and Kolb's learning styles are justifiable in light of Lane's arguments.

Meanwhile, every individual uses a number of learning styles in tackling any problemhowever in different extent-which lead to the conclusion that there is significant correlation between different four types of learning styles and slang learning and this point is emphasized by Ata and Cevik, (2018); Silver, Strong and Perini (1997) who emphasize the balance among different types of learning styles. Hence, the study also indicated that it is not a predominant learning style that may result into the increase and improvement of the slang learning but the balance among the four Kolb's Learning Styles and the total learning style is crucial and fundamental. Meanwhile, personality characteristics especially the balance among the learning styles influence and improve language learning including slang learning as it is also discussed by Wong (2011).

\section{CONCLUSION}

It was concluded that the learning styles and especially the balance among different learning styles are crucial at least for the situational context of learning English as a Foreign Language (EFL). The study also concluded that gender is not a variable differentiating between the two genders in terms of either learning styles or learning achievements of slang. The importance and balance between the two learning styles of the Concrete Experience (CE) and Abstract Conceptualization (AC) as the learning styles which play the most contribution in slang learning. The results of the study indicated a high, significant and positive regression total learning style, the four types of Kolb's learning styles, i.e. Concrete Experience (CE), Reflective Observation (RO), Abstract Conceptualization (AC), and Active Experimentation (AE) and gender with the slang learning. Accordingly, slang learning in an EFL situational context demands considering not only the lexical and cultural background - a point which is discussed by Banjar (2014) - but also the learning styles which the study proved to be significantly correlated. It means that processes apparently play fundamental role

\section{LIMITATIONS OF THE STUDY}

In this study, the researcher was attempting to do a comprehensive study in order to provide more generalizable results, the allocated time and place of the researcher did not 
let her do this. Accordingly, the researcher did not have access to the EFL students studying at the B.A. degree in other universities or even M.A. degree in Tehran University. Furthermore, due to some students' low proficiency, it appeared to be impossible to include freshmen who were just in the first year of studying English as a foreign language

\section{REFERENCES}

Abel, B. (2003). English slang in the first language and second language lexicon: A dual representation style. Second Language Research, 19(4), 329-358.

Alzain, A., Clark, S., Ireson, G., \& Jwaid, A. (2018). Adaptive education based on learning styles: are learning style instruments precise enough? International Journal of Emerging Technologies in Learning, 13(09), 41-52.

Akpan, J. P., \& Beard, L. A. (2016). Using constructivist teaching strategies to enhance academic outcomes of students with special needs. Universal Journal of Educational Research, 4(2), 392-398.

Ata, R., \& Cevik, M. (2018). Exploring relationships between Kolb's learning styles and mobile learning readiness of pre-service teachers: A mixed study. Education and Information Technologies, 6(2), 1-27.

Banjar.M. (2014). Helping learners adapt to unfamiliar methods. ELT Journal, 40, 13 19.

Barzegar, F., \& Tajalli, G. (2013). Relationship Between Learning Styles of Advanced Iranian EFL Learners and Their Achievement. Journal of Studies in Learning and Teaching English, 1(4), 1-21.

Boreham, N. C. (1987). Learning from experience in diagnostic problem solving. In Student Learning: Research in Education and Cognitive Psychology, eds., J. T. E. Richardson, M. W.

Boud, D., R. Keogh, and D. Walker, eds. (1985). Reflection: Turning Experience into Learning. London, UK: Kogan Page.

Cuevas, J., \& Dawson, B. L. (2018). A test of two alternative cognitive processing models: Learning styles and dual coding. Theory and Research in Education, 16(1), 4064 .

Dunn, R. S., \& Dunn, K. J. (1993). Teaching secondary students through their individual learning styles: Practical approaches for grades. 7-12. NY: Prentice Hall Publication Company.

Edwards, L. (2007). Solutions Placement Test: Elementary to Intermediate. Oxford Exam Support: Oxford University Press.

Günes, C. (2004). Learning style preferences of preparatory school students at Gazi University. Unpublished Doctoral dissertation, Middle East Technical University, Turkey, Ankara. 
Henry, J. (1989). Meaning and practice in experiential learning. In Making Sense of Experiential Learning: Diversity in Theory andPractice, eds., S. W. Weil and I. McGill, pp. 25-37. Milton Keynes, UK Society for Research into Higher Education and Open University Press.

In'am, Akhsanul, \& Hajar, S. (2017). Learning Geometry through discovery learning using a scientific approach akhsanul. International Journal of Instruction, 10(1), 55-70.

Kadir, M. B. B. A. (2013). The Relationship between Students' Learning Style and Academic Performance in Mara Professional College, Malaysia. The Asian Conference on Education, Osaka, Japan.

Khalid, R., Mokhtar, A. A., Omar-Fauzee, M. S., Kasim, A. L., Don, Y., Abdussyukur, N. F., Ponajan, F., A., Mahyuddin, A., Ghazali, S., N., B., Rosli,M., H, \& Geok, S. K. (2013). The Learning Styles and Academic Achievements among Arts and Science Streams Student. International Journal of Academic Research in Progressive Education and Development, 2(2), 68-85.

Kolb, A. Y., \& Kolb, D. a. (2005). Learning styles and learning spaces: Enhancing experiential learning in higher education. Academy of Management Learning \& Education, 4(2), 193-212.

Kolb, A. Y. (2006). The Kolb learning style inventory-version 3.12005 technical specifications. Boston, MA: Hay Resource Direct.

Kolb, D. A. (1984). Experiential learning: Experience as the source of learning and development (Vol. 1). Englewood Cliffs, NJ: Prentice-Hall.

Kolb, D. A., Boyatzis, R. E., \& Mainemelis, C. (2000). In RJ Sternberg \& LF Zhang. Perspectives on cognitive, learning, and thinking styles, 227-247.

Kolb, D., \& Fry, R. (1975). Towards an applied theory of experiential learning. In Theories of Group Processes, ed., C. L. Copper, pp. 33-58. London, UK John Wiley.

Lane, J. (2001). Two decades of classroom research. In B. J. Fraser \& H. J. Walberg (Eds.), Educational environments: Evaluation antecedents, and consequences, (pp. 327), Oxford; New York: Pergamon Press 1st edition.

Lewis, M. (1993). The lexical style: The state of ELT and the way forward. Hove, England: Language Teaching Publications.

Lewis, M. (1997). Implementing the Lexical Style: Putting Theory into Practice. Hove, England: Language Teaching Publications.

McCarthy, M., \& O'dell, F. (2003). English vocabulary in use. Cambridge: CUP.

McGavigan, P. (2009). The acquisition of fixed idioms in Greek learners of English as a foreign language. Unpublished PhD dissertation, Swansea University, UK, Wales. 
Mohammadzadeh, A. (2012). The Relationship between Experiential Learning Styles and the Immediate and Delayed Retention of English Collocations among EFL Learners. English Language Teaching, 5(12), 121-130.

Moser, S., \& Zumbach, J. (2018). Exploring the development and impact of learning styles: An empirical investigation based on explicit and implicit measures. Computers \& Education.

Nasab, F. G., \& Hesabi, A. (2014). On the relationship between learning style and the use of pictures in comprehension of Idioms among Iranian EFL learners. Theory and Practice in Language Studies, 4(9), 1892-1897.

Nippold, M.A., Maron, C., \& Schwrrz, I. E. (2001). Idioms understanding in preadolescents: Synergy in action. American Journal of Speech-Language Pathology, 10, 169-181.

Nippold, M. A., \& Taylor, C. L. (2002). Judgments of Idiom Familiarity and Transparency: A Comparison of Children and Adolescents. Journal of Speech, Language, and Hearing Research, 45(2), 384-391.

Reid, J. (1987). Perceptual learning style preferences of international students. Paper presented at the National NAFSA Conference, Cincinnati.

Reshmad'sa, L., \& Vijayakumari, S. N. (2017). Effect of Kolb's Experiential Learning Strategy on Enhancing Pedagogical Skills of Pre-Service Teachers of Secondary School Level. Journal on School Educational Technology, 13(2),39-42.

Rodriguez, J.K. \& Winnberg, H. (2013). Teaching Idiomatic Expressions in Language Classrooms-Like the Icing on the Cake. Malmo hogskola. Retrieved on August, 18, 2017from:https://muep.mau.se/handle/2043/16123

Rogowsky, B. A., Calhoun, B. M., \& Tallal, P. (2015). Matching learning style to instructional method: Effects on comprehension. Journal of Educational Psychology, 107(1), 64-78.

Rundell, M., \& Fox, G. (2007). Macmillan English dictionary for advanced learners. London: Macmillan.

Saberian, N., \& Fotovatnia, Z. (2011). Idiom taxonomies and idiom comprehension: Implications for English teachers. Theory and practice in language studies, 1(9), 12311235.

Schmitt, N. (2000). Vocabulary in Language Teaching. Cambridge: Cambridge University Press.

Smith, K. L., \& Rayfield, J. (2017). Student Teaching Changed Me: A Look at Kolb's Learning Style Inventory Scores Before and After the Student Teaching Experience. Journal of Agricultural Education, 58(1),102-118.

Silver, H., Strong, R., \& Perini, M. (1997). Integrating learning styles and multiple intelligences. Educational Leadership, 55(1), 22-27. 
Slavin, R. E. (2000). Educational Psychology: Theory and Practice (6 ${ }^{\text {th }}$ Ed.). New York: Pearson Education Company.

Stoneback, S. (2014). Application of the Kolb Learning Style Inventory and Border's Adaptation of the Model to Trumpet Instruction in the Applied Collegiate Trumpet Studio. International Journal of Instruction, 11(1), 89-102.

Sudria, I. B. N., Redhana, I. W., Kirna, I., \& Aini, D. (2018). Effect of Kolb's Learning Styles under Inductive Guided-Inquiry Learning on Learning Outcomes. International Journal of Instruction, 11(1), 89-102. https://doi.org/10.12973/iji.2018.1117a

Swari, P. P (2015). Learning style analysis of high school students in Buleleng on Chemical education in terms of module Kolb learning styles. Thesis (Unpublished). Singaraja: Universitas Pendidikan Ganesha.

Yousafzai, Y. M., Baseer, N., Fatima, S., Ali, A., \& Shah, I. (2018). Changes in learning style preferences of postgraduates after entering a new learning environment. Journal of Ayub Medical College Abbottabad, 30(3), 417-422.

Vizeshfar, F., \& Torabizadeh, C. (2018). The effect of teaching based on dominant learning style on nursing students' academic achievement. Nurse education in practice, 28, 103-108. DOI: http://dx.doi.org/10.1016/j.nepr.2017.10.013

Wong, E. (2011). Extraversion and introversion in second-language acquisition: a literature review. Bulletin of the Nihon University School of Dentistry 39, 1-10.

Worley-Davis, L. (2012). A Comparison of Learning Styles and Academic Performance of Students Enrolled in Introductory Poultry Science Courses in Bachelors of Science and Associates of Applied Science Programs. Unpublished MA thesis, North Carolina State University, USA, Raleigh, North Carolina.

Zhu, H. R., Zeng, H., Zhang, H., Zhang, H. Y., Wan, F. J., Guo, H. H., \& Zhang, C. H. (2018). The preferred learning styles utilizing VARK among nursing students with bachelor degrees and associate degrees in China. Acta Paulista de Enfermagem, 31(2), 162-169.

Zuber-Skerritt, O. (1992a). Professional development in higher education: A theoretical framework for action research. London, UK: Kogan Page. 